\title{
Synthesis of Azole-fused Benzothiadiazoles as Key Units for Functional $\pi$-Conjugated Compounds
}

\author{
Tomoya Nakamura, Shuhei Okazaki, Noriko Arakawa, Motoi Satou, Masaru Endo, \\ Yasujiro Murata, and Atsushi Wakamiya* \\ Institute for Chemical Research, Kyoto University, \\ Gokasho, Uji, Kyoto 611-0011, Japan \\ *wakamiya@scl.kyoto-u.ac.jp
}

\begin{abstract}
2,1,3-Benzothiadiazole (BT) is a widely used electron-accepting unit in organic electronics including organic solar cells (OSCs). As modifications of BT skeleton, two types of azolefused BT units were designed and synthesized; thiazole-fused BT with an electronwithdrawing $\mathrm{C}=\mathrm{N}$ bond and imidazole-fused $\mathrm{BT}$ with an electron-donating nitrogen atom as well as an electron-withdrawing $\mathrm{C}=\mathrm{N}$ bond. Electrochemical measurements and theoretical calculations suggest that thiazole-fusion enhances the electron-accepting ability, whereas imidazole-fusion endows the BT skeleton with electron-donating ability while maintaining its electron-accepting ability. Moreover, in thiazole-fused BT units, the electronic structure could be further modulated by varying the oxidation state of the sulfur atom in methylthio group at the fused thiazole ring.
\end{abstract}

Keywords: Benzothiadiazole, Acceptor unit, Ring-fusion, Thiazole, Imidazole

\section{Introduction}

2,1,3-Benzothiadiazole (BT) is a widely used electron-accepting unit in organic electronics [1-5]. Modified BT derivatives, such as 5,6-difluoro-BT, thiadiazoloquinoxaline, benzobisthiadiazole, naphthobisthiadiazole have been synthesized $[6,7]$. By the combination of these BT derivatives with electron-donating units, various donor-acceptor (D-A) polymers have been developed and utilized as photoelectric conversion materials in organic solar cells (OSCs). The outstanding characteristics of BT unit are the effective extension of $\pi$ conjugation as well as high electron-accepting ability, which could be explained by the considerable contribution of butadiene character and the presence of two electron-withdrawing $\mathrm{C}=\mathrm{N}$ bonds (Fig. 1a). Similarly, another representative electron-accepting unit, diketopyrrolopyrrole (DPP) [8-10], can be regarded as butadiene moiety connected by electron-donating nitrogen atoms as well as electron-withdrawing $\mathrm{C}=\mathrm{O}$ bonds (Fig. 1b).

In this paper, we describe two types of azolefusion as further modifications of BT skeleton; thiazole-fusion and imidazole-fusion (Fig. 1c, d). We anticipated that thiazole-fusion enables the (a)

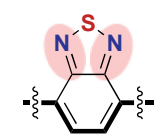

Benzothiadiazole (BT)

(c)

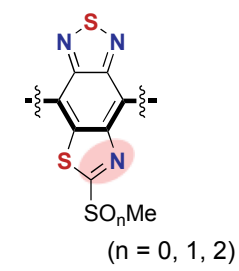

Thiazole-fused BT (b)

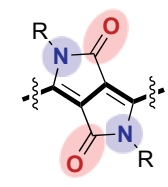

Diketopyrrolopyrrole (DPP)

(d)

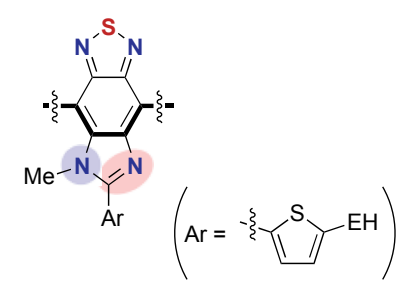

Imidazole-fused BT

Fig. 1. Diene character in (a) benzothiadiazole (BT) and (b) diketopyrrolopyrrole (DPP), and the molecular design of (c) thiazole-fused BT and (d) imidazole-fused BT.

further lowering of LUMO energy level by the existence of the electron-withdrawing imine moiety [11,12] (Fig. 2). Moreover, the LUMO energy level can be further controlled by changing the oxidation state of the substituted methylthio group. Imidazolefusion is expected to induce the increase of HOMO energy level by the existence of an electron- 
donating amine moiety while maintaining the LUMO level by the imine moiety (Fig. 2). Here we report the synthesis of thiazole-fused and imidazolefused BT skeletons as key building units for functional $\pi$-conjugated compounds, and discuss the effect of azole-fusion on the electronic structure.

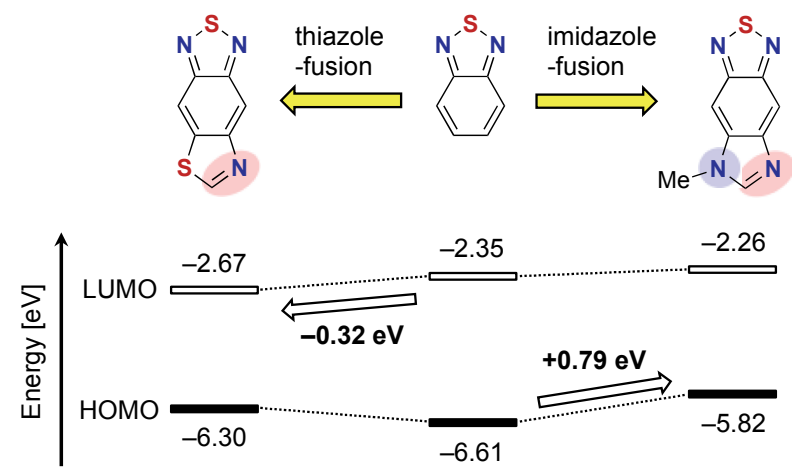

Fig. 2. Effect of azole-fusion on the electronic structure of BT skeleton. Calculated at B3LYP/6-31G(d) level of theory [13].

\section{Experimental}

\subsection{General information}

Melting points ( $\mathrm{mp}$ ) were measured on a Yanaco Micro Melting Point Apparatus. ${ }^{1} \mathrm{H}$ and ${ }^{13} \mathrm{C}$ NMR spectra were recorded with a JEOL JNM ECA500 (500 MHz for ${ }^{1} \mathrm{H}$ and $126 \mathrm{MHz}$ for ${ }^{13} \mathrm{C}$ ). Chemical shifts were reported in $\delta$ ppm using residual protons in the deuterated solvents for ${ }^{1} \mathrm{H}$ NMR and using solvent peaks for ${ }^{13} \mathrm{C}$ NMR as internal standards. IR spectra were taken with a Shimadzu FTIR-8400S spectrometer. Mass spectra were measured on a Bruker micrOTOF-Q II (APCI) and JEOL JMSMS700V (FAB). Cyclic voltammetry (CV) was performed on an ALS/chi-620C electrochemical analyzer. The CV cell consisted of a glassy carbon electrode, a $\mathrm{Pt}$ wire counter electrode, and an $\mathrm{Ag} / \mathrm{AgNO}_{3}$ reference electrode. The measurement was carried out under an argon atmosphere using $\mathrm{CH}_{2} \mathrm{Cl}_{2}$ solutions of samples $(1 \mathrm{mM})$ with $0.1 \mathrm{M}$ tetrabutylammonium hexafluorophosphate $\left(\mathrm{Bu}_{4} \mathrm{~N}^{+} \mathrm{PF}_{6}{ }^{-}\right)$as a supporting electrolyte. The redox potentials were calibrated with ferrocene as an internal standard. Thin layer chromatography (TLC) was performed on plates coated with $0.25 \mathrm{~mm}$ thick silica gel 60F-254 (Merck). Column chromatography was performed using silica gel PSQ 60B (Fuji Silysia) or PSQ 100B (Fuji Silysia). All reactions were carried out under an argon atmosphere except as otherwise noted.

\subsection{Computation method}

All calculations were conducted using the Gaussian 09 program [13]. The geometries were optimized at the B3LYP/6-31G(d) level of theory. The fact that these geometries are at the energy minimum was confirmed by frequency calculations at the same level of theory.

\subsection{Synthesis}

\subsection{1. \\ 2-(Methylthio)-1,3-benzothiazole-5,6- diamine (6)}

To a $1 \mathrm{~L}$ two-necked flask were added 2-chloro-5nitrobenzene-1,4-diamine (3) (10.0 g, $53.3 \mathrm{mmol})$, sodium ethylxanthate $(16.9 \mathrm{~g}, 117 \mathrm{mmol})$, and dry DMF $(350 \mathrm{~mL})$. The mixture was stirred at $100^{\circ} \mathrm{C}$ for $2.5 \mathrm{~h}$ and then cooled in a water bath. Methyl iodide $(8.29 \mathrm{~mL}, 133 \mathrm{mmol})$ was added dropwise, and the mixture was stirred for $17.5 \mathrm{~h}$. The reaction mixture was poured into water. The formed orange precipitates were collected by filtration, washed with water, and dried under vacuum at $50{ }^{\circ} \mathrm{C}$ to give benzothiazole 5 , which was used in the next reaction without further purification.

To a $1 \mathrm{~L}$ two-necked flask were added 5 (11.8 g, $48.9 \mathrm{mmol}), \mathrm{SnCl}_{2} \cdot 2 \mathrm{H}_{2} \mathrm{O}(55.0 \mathrm{~g}, 244 \mathrm{mmol})$, $\mathrm{MeOH}(480 \mathrm{~mL})$, distilled water $(68 \mathrm{~mL})$, and $\mathrm{HCl}$ aq. (12 M, $1.8 \mathrm{~mL}, 22 \mathrm{mmol})$. The mixture was stirred at $70{ }^{\circ} \mathrm{C}$ for $22 \mathrm{~h}$. The reaction mixture was concentrated under reduced pressure and then neutralized with saturated $\mathrm{Na}_{2} \mathrm{CO}_{3}$ aq. $(500 \mathrm{~mL})$. The formed precipitates were collected by filtration, washed with water, and dried under vacuum at $50{ }^{\circ} \mathrm{C}$. The crude product was purified by silica gel column chromatography (methanol $/ \mathrm{CH}_{2} \mathrm{Cl}_{2}=1: 10$ as eluent, $\left.R_{\mathrm{f}}=0.25\right)$ to give $\mathbf{6}(11.3 \mathrm{~g}, 65 \%$ from 3$)$ as yellow solids.

mp: $141.5-142.3{ }^{\circ} \mathrm{C} ;{ }^{1} \mathrm{H}$ NMR (500 MHz, DMSO$\left.d_{6}\right): \delta 6.98(\mathrm{~s}, 1 \mathrm{H}), 6.92(\mathrm{~s}, 1 \mathrm{H}), 4.76(\mathrm{~s}, 2 \mathrm{H}), 4.71$ (s, 2H), $2.67(\mathrm{~s}, 3 \mathrm{H}) ;{ }^{13} \mathrm{C}$ NMR (126 MHz, DMSO$\left.d_{6}\right): \delta 159.39,146.14,135.58,134.84,123.38$, 105.32, 103.97, 15.65; HRMS (FAB) (m/z): [M] calcd. for $\mathrm{C}_{8} \mathrm{H}_{9} \mathrm{~N}_{3} \mathrm{~S}_{2}, 211.0238$; found, 211.0239.

\subsubsection{6-(Methylthio)thiazolo[5,4-f]-2,1,3-} benzothiadiazole (7)

To a $500 \mathrm{~mL}$ two-necked flask were added 6 (3.00 g, $14.2 \mathrm{mmol})$, distilled triethylamine $(15.8 \mathrm{~mL}, 114$ $\mathrm{mmol})$, and $\mathrm{CH}_{2} \mathrm{Cl}_{2}(200 \mathrm{~mL})$, and the mixture was cooled in an ice bath. $\mathrm{SOCl}_{2}(4.20 \mathrm{~mL}, 57.9 \mathrm{mmol})$ was added dropwise over $25 \mathrm{~min}$. The mixture was allowed to warm to room temperature and was stirred for $17 \mathrm{~h}$. The resulting mixture was neutralized with saturated $\mathrm{Na}_{2} \mathrm{CO}_{3}$ aq. $(150 \mathrm{~mL})$, 
and the aqueous phase was extracted with $\mathrm{CH}_{2} \mathrm{Cl}_{2}$ $(150 \mathrm{~mL} \times 4)$. The combined organic layers were dried over $\mathrm{Na}_{2} \mathrm{SO}_{4}$, filtered, and concentrated under reduced pressure. The crude product was purified by silica gel column chromatography $\left(\mathrm{CH}_{2} \mathrm{Cl}_{2}\right.$ as eluent, $\left.R_{\mathrm{f}}=0.57\right)$ to give $7(3.21 \mathrm{~g}, 94 \%)$ as yellow solids. mp: $171.5-172.4{ }^{\circ} \mathrm{C} ;{ }^{1} \mathrm{H}$ NMR $\left(500 \mathrm{MHz}, \mathrm{CDCl}_{3}\right.$ ): $\delta 8.37(\mathrm{~s}, 1 \mathrm{H}), 8.32(\mathrm{~s}, 1 \mathrm{H}), 2.87(\mathrm{~s}, 3 \mathrm{H}) ;{ }^{13} \mathrm{C} \mathrm{NMR}$ $\left(126 \mathrm{MHz}, \mathrm{CDCl}_{3}\right): \delta$ 172.94, 155.69, 153.93, $152.00,140.61,111.68,110.53,15.76$; HRMS (FAB) (m/z): $[\mathrm{M}]^{+}$calcd. for $\mathrm{C}_{8} \mathrm{H}_{5} \mathrm{~N}_{3} \mathrm{~S}_{3}, 238.9646$; found, 238.9646.

\subsubsection{4,8-Dibromo-6-(methylthio)thiazolo[5,4-f]-} 2,1,3-benzothiadiazole (1a)

To a $100 \mathrm{~mL}$ two-necked flask were added 7 (3.16 $\mathrm{g}, 13.2 \mathrm{mmol})$ and $\mathrm{FeCl}_{3} \cdot 6 \mathrm{H}_{2} \mathrm{O}(2.16 \mathrm{~g}, 7.99 \mathrm{mmol})$. $\mathrm{Br}_{2}(22.0 \mathrm{~mL}, 427 \mathrm{mmol})$ was added, and the mixture was stirred at $50{ }^{\circ} \mathrm{C}$ for $5 \mathrm{~h}$. Saturated $\mathrm{NaHSO}_{3}$ aq. $(200 \mathrm{~mL})$ was added to consume the excess bromine. The formed precipitates were collected by filtration, washed with water, and dried under vacuum at $50{ }^{\circ} \mathrm{C}$. The crude product was purified by silica gel column chromatography $\left(\mathrm{CHCl}_{3}\right.$ as eluent, $\left.R_{\mathrm{f}}=0.78\right)$ to give $1 \mathrm{a}(4.85 \mathrm{~g}, 92 \%)$ as yellow solids.

mp: $241.0-241.8^{\circ} \mathrm{C} ;{ }^{1} \mathrm{H}$ NMR (500 MHz, $\left.\mathrm{CDCl}_{3}\right)$ : $\delta 2.92(\mathrm{~s}, 3 \mathrm{H}) ;{ }^{13} \mathrm{C}$ NMR $\left(126 \mathrm{MHz}, \mathrm{CDCl}_{3}\right): \delta$ $173.60,152.53,152.15,149.82,142.84,102.96$, 102.37, 16.15; HRMS (APCI) (m/z): $[\mathrm{M}+\mathrm{H}]^{+}$calcd. for $\mathrm{C}_{8} \mathrm{H}_{4} \mathrm{Br}_{2} \mathrm{~N}_{3} \mathrm{~S}_{3}, 395.7929$; found, 395.7913 .

\subsubsection{4,8-Dibromo-6-(methylsulfinyl)thiazolo[5,4-} f]-2,1,3-benzothiadiazole (1b)

To a $100 \mathrm{~mL}$ two-necked flask were added $\mathbf{1 a}$ (199 mg, $0.50 \mathrm{mmol})$ and $\mathrm{CHCl}_{3}(40 \mathrm{~mL})$. After cooled to $0{ }^{\circ} \mathrm{C}, \mathrm{mCPBA}(124 \mathrm{mg}, 0.50 \mathrm{mmol})$ was added, and the mixture was stirred at $0{ }^{\circ} \mathrm{C}$ for $4 \mathrm{~h}$. Saturated $\mathrm{NaHSO}_{3}$ aq. $(40 \mathrm{~mL})$ was added, and the aqueous phase was extracted with $\mathrm{CHCl}_{3}(30 \mathrm{~mL} \times$ $2)$. The combined organic layers were dried over $\mathrm{Na}_{2} \mathrm{SO}_{4}$, filtered, and concentrated under reduced pressure. The crude product was purified by silica gel column chromatography $\left(\mathrm{CHCl}_{3}\right.$ as eluent, $R_{\mathrm{f}}=$ $0.43)$ to give $1 \mathbf{b}(154 \mathrm{mg}, 75 \%)$ as yellow solids.

mp (decomp.): $271.2{ }^{\circ} \mathrm{C}$; IR (KBr) $v=1070 \mathrm{~cm}^{-1}$ $\left(\mathrm{S}=\mathrm{O}\right.$, sulfoxide); ${ }^{1} \mathrm{H}$ NMR (500 MHz, $\left.\mathrm{CDCl}_{3}\right): \delta$ $3.20(\mathrm{~s}, 3 \mathrm{H}) ;{ }^{13} \mathrm{C}$ NMR $\left(126 \mathrm{MHz}, \mathrm{CDCl}_{3}\right): \delta 185.79$, $152.65,152.02,150.45,141.83,107.85,104.83$, 43.07; HRMS (APCI) $(\mathrm{m} / \mathrm{z}):[\mathrm{M}+\mathrm{H}]^{+}$calcd. for $\mathrm{C}_{8} \mathrm{H}_{4} \mathrm{Br}_{2} \mathrm{~N}_{3} \mathrm{OS}_{3}$, 411.7878; found, 411.7867 .

2.3.5. 4,8-Dibromo-6-(methylsulfonyl)- thiazolo[5,4-f]-2,1,3-benzothiadiazole (1c)

To a $100 \mathrm{~mL}$ two-necked flask were added 1a (199 mg, $0.50 \mathrm{mmol}$ ) and $\mathrm{CHCl}_{3}(40 \mathrm{~mL}) . \mathrm{mCPBA}$ (493 mg, $2.00 \mathrm{mmol}$ ) was added and the mixture was stirred at room temperature for $30 \mathrm{~h}$. Saturated $\mathrm{NaHSO}_{3}$ aq. $(20 \mathrm{~mL})$ was added, and the aqueous phase was extracted with $\mathrm{CHCl}_{3}(20 \mathrm{~mL} \times 2)$. The combined organic layers were dried over $\mathrm{Na}_{2} \mathrm{SO}_{4}$, filtered, and concentrated under reduced pressure. The crude product was purified by silica gel column chromatography $\left(\mathrm{CHCl}_{3}\right.$ as eluent, $\left.R_{\mathrm{f}}=0.57\right)$ to give 1c $(157 \mathrm{mg}, 73 \%)$ as yellow solids.

mp (decomp.): $275.4{ }^{\circ} \mathrm{C}$; IR (KBr) $v=1324,1148$ $\mathrm{cm}^{-1}\left(\mathrm{~S}=\mathrm{O}\right.$, sulfone); ${ }^{1} \mathrm{H}$ NMR $\left(500 \mathrm{MHz}, \mathrm{CDCl}_{3}\right)$ : $\delta 3.54(\mathrm{~s}, 3 \mathrm{H}) ;{ }^{13} \mathrm{C}$ NMR $\left(126 \mathrm{MHz}, \mathrm{CDCl}_{3}\right): \delta$ $171.12,152.29,151.09,150.88,141.59,110.45$, 104.85, 41.70; HRMS (APCI) (m/z): [M+H] $]^{+}$calcd. for $\mathrm{C}_{8} \mathrm{H}_{4} \mathrm{Br}_{2} \mathrm{~N}_{3} \mathrm{O}_{2} \mathrm{~S}_{3}, 427.7827$; found, 427.7807 .

2.3.6. 4,8-Dibromo-6-(5-(2-ethylhexyl)thiophen-2yl)-5H-imidazo[5,4-f]-2,1,3-benzothiadiazole (11)

To a Schlenk tube were added $\mathbf{1 0}$ (234 mg, 0.721 mmol), dry DMSO (5.0 mL), TFA $(11 \mu \mathrm{L}, 0.14$ mmol) and 5-(2-ethylhexyl)thiophene-2carbaldehyde $(210 \mu \mathrm{L}, 0.759 \mathrm{mmol})$. The mixture was stirred at $100{ }^{\circ} \mathrm{C}$ for $16.5 \mathrm{~h}$ and then cooled to room temperature. DDQ (418 $\mathrm{mg}, 1.84 \mathrm{mmol}$ ) was added, and the mixture was stirred at $40{ }^{\circ} \mathrm{C}$ for 0.5 $\mathrm{h}$. The reaction mixture was poured into saturated $\mathrm{NaHCO}_{3}$ aq. $(80 \mathrm{~mL})$. The formed yellow precipitates were collected by filtration and washed with water. The residue was then dissolved in $\mathrm{CH}_{2} \mathrm{Cl}_{2}$, dried over $\mathrm{Na}_{2} \mathrm{SO}_{4}$, filtered, and concentrated under reduced pressure. The crude product was purified by silica gel column chromatography $\left(\mathrm{CH}_{2} \mathrm{Cl}_{2}\right.$ as eluent, $\left.R_{\mathrm{f}}=0.27\right)$ to give 11 (333 $\mathrm{mg}, 87 \%)$ as yellow solids.

mp: 223.9-224.9 ${ }^{\circ} \mathrm{C} ;{ }^{1} \mathrm{H}$ NMR $\left(500 \mathrm{MHz}, \mathrm{CDCl}_{3}\right)$ : $\delta 7.83(\mathrm{~d}, J(\mathrm{H}, \mathrm{H})=4.0 \mathrm{~Hz}, 1 \mathrm{H}), 6.89(\mathrm{~d}, J(\mathrm{H}, \mathrm{H})=$ $4.0 \mathrm{~Hz}, 1 \mathrm{H}), 2.82(\mathrm{~d}, J(\mathrm{H}, \mathrm{H})=6.5 \mathrm{~Hz}, 2 \mathrm{H}), 1.65(\mathrm{~m}$, 1H), $1.39-1.25(\mathrm{~m}, 8 \mathrm{H}), 0.92-0.87(\mathrm{~m}, 6 \mathrm{H}) ;{ }^{13} \mathrm{C}$ NMR $\left(126 \mathrm{MHz}, \mathrm{DMF}-d_{7}\right): \delta$ 156.36, 153.11, 151.11 (2C), 149.01, 141.62, 132.70, 130.79, $128.69,98.95,89.70,42.51,34.97,33.36,29.72$, 26.49, 23.86, 14.73, 11.45; HRMS (APCI) (m/z): $[\mathrm{M}+\mathrm{H}]^{+}$calcd. for $\mathrm{C}_{19} \mathrm{H}_{21} \mathrm{Br}_{2} \mathrm{~N}_{4} \mathrm{~S}_{2}, 526.9569$; found, 526.9569 .

2.3.7. 4,8-Dibromo-6-(5-(2-ethylhexyl)thiophen-2yl)-5-methyl-imidazo[5,4-f]-2,1,3-benzothiadiazole (2)

In a Schlenk tube were added $\mathbf{1 1}$ (603 mg, 1.14 mmol), dry DMF (3.0 mL), $\mathrm{K}_{2} \mathrm{CO}_{3}(320 \mathrm{mg}, 2.32$ 
mmol), and methyl iodide ( $141 \mu \mathrm{L}, 2.26 \mathrm{mmol})$. The mixture was stirred at $100{ }^{\circ} \mathrm{C}$ for $16.5 \mathrm{~h}$ and then poured into saturated $\mathrm{NH}_{4} \mathrm{Cl}$ aq. $(150 \mathrm{~mL})$. The formed yellow precipitates were collected by filtration and washed with water. The residue was then dissolved in $\mathrm{CH}_{2} \mathrm{Cl}_{2}$, dried over $\mathrm{Na}_{2} \mathrm{SO}_{4}$, filtered, and concentrated under reduced pressure. The crude product was purified by silica gel column chromatography $\left(\mathrm{CH}_{2} \mathrm{Cl}_{2}\right.$ as eluent, $\left.R_{\mathrm{f}}=0.47\right)$ to give $2(365 \mathrm{mg}, 50 \%)$ as yellow solids.

mp: $136.8-137.3{ }^{\circ} \mathrm{C} ;{ }^{1} \mathrm{H}$ NMR $\left(500 \mathrm{MHz}, \mathrm{CDCl}_{3}\right)$ : $\delta 7.60(\mathrm{~d}, J(\mathrm{H}, \mathrm{H})=3.5 \mathrm{~Hz}, 1 \mathrm{H}), 6.91(\mathrm{~d}, J(\mathrm{H}, \mathrm{H})=$ $4.0 \mathrm{~Hz}, 1 \mathrm{H}), 4.38(\mathrm{~s}, 3 \mathrm{H}), 2.84(\mathrm{~d}, J(\mathrm{H}, \mathrm{H})=7.0 \mathrm{~Hz}$, $2 \mathrm{H}), 1.68(\mathrm{~m}, 1 \mathrm{H}), 1.42-1.31(\mathrm{~m}, 8 \mathrm{H}), 0.94-0.89(\mathrm{~m}$, $6 \mathrm{H}) ;{ }^{13} \mathrm{C} \mathrm{NMR}\left(126 \mathrm{MHz}, \mathrm{CDCl}_{3}\right): \delta 157.15,152.36$, $150.65,149.90,147.44,138.97,131.52,127.79$, $126.69,100.09,89.53,41.58,35.30,34.31,32.39$, 28.83, 25.52, 22.96, 14.11, 10.79; HRMS (APCI) $(\mathrm{m} / \mathrm{z}):[\mathrm{M}+\mathrm{H}]^{+}$calcd. for $\mathrm{C}_{20} \mathrm{H}_{23} \mathrm{Br}_{2} \mathrm{~N}_{4} \mathrm{~S}_{2}, 540.9725$; found, 540.9700 .

\subsection{X-Ray crystal structure analysis}

Crystallographic data have been deposited with the Cambridge Crystallographic Data Center as supplementary publication no. CCDC-1540942 (1a) and CCDC-1540941 (2). These data can be obtained free of charge from The Cambridge Crystallographic Data Centre via www.ccdc.cam.ac.uk/data_request/cif.

\subsubsection{Compound 1a}

Single crystals suitable for X-ray analysis were obtained by diffusion of methanol into a solution of $1 \mathrm{a}$ in $\mathrm{CH}_{2} \mathrm{Cl}_{2}$. Intensity data were collected at $100 \mathrm{~K}$ on a Bruker Single Crystal CCD X-ray Diffractometer (SMART APEX II) with Mo K $\alpha$ radiation $(\lambda=0.71073 \AA)$ and graphite monochrometer. A total of 4923 reflections were measured with a maximum $2 \theta$ angle of $51.0^{\circ}$, of which 2050 were independent reflections $\left(R_{\text {int }}=\right.$ 0.0230 ). The structure was solved by direct methods (SHELXS-97[14]) and refined by the full-matrix least-squares on $F^{2}$ (SHELXL-97[14]). All nonhydrogen atoms were refined anisotropically. All hydrogen atoms were placed using AFIX instructions. The crystal data are as follows: $\mathrm{C}_{8} \mathrm{H}_{3} \mathrm{Br}_{2} \mathrm{~N}_{3} \mathrm{~S}_{3} ; \mathrm{FW}=397.13$, crystal size $0.55 \times 0.07$ $\times 0.03 \mathrm{~mm}^{3}$, Monoclinic, $C 2 / \mathrm{c}, a=16.513(4) \AA, b$ $=3.9266(10) \AA, c=34.128(9) \AA, \beta=94.065(3)^{\circ}, V$ $=2207.2(10) \AA^{3}, Z=8, D_{\mathrm{c}}=2.390 \mathrm{~g} \mathrm{~cm}^{-3}$. The refinement converged to $R_{1}=0.0368, \mathrm{w} R_{2}=0.0802$ $(I>2 \sigma(I)), \mathrm{GOF}=1.336$.

\subsubsection{Compound 2}

Single crystals suitable for X-ray analysis were obtained by diffusion of hexane into a solution of 2 in $\mathrm{CH}_{2} \mathrm{Cl}_{2}$. Intensity data were collected at $100 \mathrm{~K}$ on a Bruker Single Crystal CCD X-ray Diffractometer (SMART APEX II) with Mo $\mathrm{K} \alpha$ radiation $(\lambda=$ $0.71073 \AA$ ) and graphite monochrometer. A total of 5223 reflections were measured with a maximum $2 \theta$ angle of $51.0^{\circ}$, of which 3838 were independent reflections $\left(R_{\text {int }}=0.0201\right)$. The structure was solved by direct methods (SHELXS-97[14]) and refined by the full-matrix least-squares on $F^{2}$ (SHELXL97[14]). The 2-ethylhexyl moiety (C13-C23) was partially disordered, which was solved using appropriate models. Thus, two sets of disordered parts, i.e., (C14, C19, C20) and (C21, C22, C23) were placed with the occupancy of 0.68 and 0.32 , respectively. All non-hydrogen atoms, except for the disordered carbons of C21, C22, C23, were refined anisotropically. All hydrogen atoms were placed using AFIX instructions. The crystal data are as follows: $\mathrm{C}_{20} \mathrm{H}_{18} \mathrm{Br}_{2} \mathrm{~N}_{4} \mathrm{~S}_{2} ; \mathrm{FW}=538.32$, crystal size $0.31 \times 0.29 \times 0.01 \mathrm{~mm}^{3}$, Triclinic, $P-1, a=$ 8.1304(19) $\AA, b=8.692(2) \AA, c=16.315(4) \AA, \alpha=$ $74.878(3)^{\circ}, \beta=79.871(3)^{\circ}, \gamma=73.059(3)^{\circ}, V=$ 1058.6(4) $\AA^{3}, Z=2, D_{\mathrm{c}}=1.689 \mathrm{~g} \mathrm{~cm}^{-3}$. The refinement converged to $R_{1}=0.0375, \mathrm{w} R_{2}=0.0996$ $(I>2 \sigma(I)), \mathrm{GOF}=1.084$.

\section{Results and discussion}

\subsection{Synthesis}

We have previously reported the construction of thiazole-fused BT skeleton by thermal [11] or oxidative [12] cyclization of thioamide. In those cases, aryl groups have to be introduced at 4,7position of BT before the cyclization. Here we developed a new synthetic methodology which enables the synthesis of 4,7-dibrominated derivatives (Scheme 1). The reaction of commercially available $o$-haloaniline $\mathbf{3}$ with sodium ethylxanthate gave the intermediate 4 [15], which was treated with methyl iodide to give methylthiobenzothiazole 5. Reduction of the nitro group by tin (II) chloride gave diamine 6 in $65 \%$ yield from 3 [16]. Condensation with thionyl chloride gave thiazole-fused BT 7 in $94 \%$ yield. The dibromination was achieved by the reaction with bromine in the presence of iron (III) chloride [17], which yielded 1a with a methylthio group in $92 \%$ yield. One advantage of introducing the methylthio group is that the electronic structure could be modulated by varying the oxidation state of the sulfur atom. 1b with a methylsulfoxide group was 
synthesized by the reaction with $m \mathrm{CPBA}$ at $0{ }^{\circ} \mathrm{C}$ in $75 \%$ yield, while 1c with a methylsulfonyl group was synthesized by treating with excess amount of $m \mathrm{CPBA}$ at room temperature in $73 \%$ yield [18].

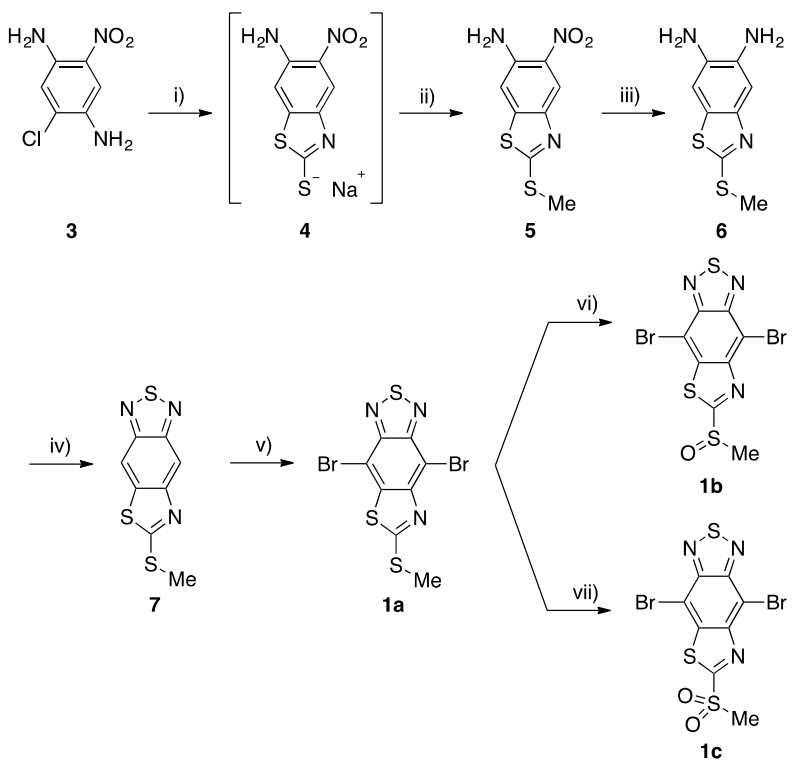

Scheme 1. Synthesis of thiazole-fused BT unit. Reagents and conditions: i) Sodium ethylxanthate (2.2 equiv), DMF, $100^{\circ} \mathrm{C}, 2.5 \mathrm{~h}$; ii) MeI (2.5 equiv), DMF, rt, $17.5 \mathrm{~h}$; iii) $\mathrm{SnCl}_{2} \cdot 2 \mathrm{H}_{2} \mathrm{O}$ (5.0 equiv), $\mathrm{MeOH} / \mathrm{HCl}$ aq., $70{ }^{\circ} \mathrm{C}, 22 \mathrm{~h}$, $65 \%$ from 3 ; iv) $\mathrm{SOCl}_{2}$ (4.1 equiv), $\mathrm{Et}_{3} \mathrm{~N}$ (8.0 equiv), $\mathrm{CH}_{2} \mathrm{Cl}_{2}, 0{ }^{\circ} \mathrm{C}$ to rt, $17 \mathrm{~h}, 94 \%$; v) $\mathrm{Br}_{2}$ (32 equiv), $\mathrm{FeCl}_{3} \cdot 6 \mathrm{H}_{2} \mathrm{O}$ (0.6 equiv), $50{ }^{\circ} \mathrm{C}, 5 \mathrm{~h}, 92 \%$; vi) $m \mathrm{CPBA}$ (1.0 equiv), $\mathrm{CHCl}_{3}, 0{ }^{\circ} \mathrm{C}, 4 \mathrm{~h}, 75 \%$; vii) $m \mathrm{CPBA}$ (4.0 equiv), $\mathrm{CHCl}_{3}$, rt, $30 \mathrm{~h}, 73 \%$.

For the synthesis of imidazole-fused BT unit, diamine $\mathbf{1 0}$ was synthesized from commercially available dibromobenzothiadiazole $\mathbf{8}$ following the reported procedure [19]. Construction of the fused imidazole ring was achieved by the condensation of $\mathbf{1 0}$ with arylaldehyde $[20,21]$ using TFA as a catalyst, which yielded 11 in $87 \%$ yield (Scheme 2). Finally, methylation of imidazole [22] afforded the imidazole-fused BT 2 in 50\% yield.

\subsection{Crystal structure}

Single crystals of 1a or $\mathbf{2}$ were obtained from slow diffusion of methanol or hexane into the solution in $\mathrm{CH}_{2} \mathrm{Cl}_{2}$, respectively. X-ray diffraction analyses of these crystals confirmed that thiazolefused and imidazole-fused BT adopt highly planar structures, and the dihedral angle between the fused imidazole and the thiophene ring was $8.0^{\circ}$ (Fig. 3). In thiazole-fused BT 1a, the bond lengths for $\mathrm{C} 2-$

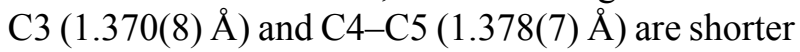
than the other bond lengths in the benzene ring, similar to the bond alternation in $\mathbf{8}(1.356(7) \AA$ and 1.364(6) $\AA$ ) [23]. The same trend was observed for imidazole-fused BT 2, with the bond length of C2-

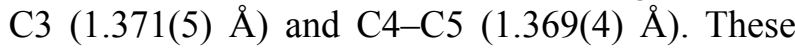
features suggest the considerable contribution of butadiene character in these azole-fused BT skeletons.
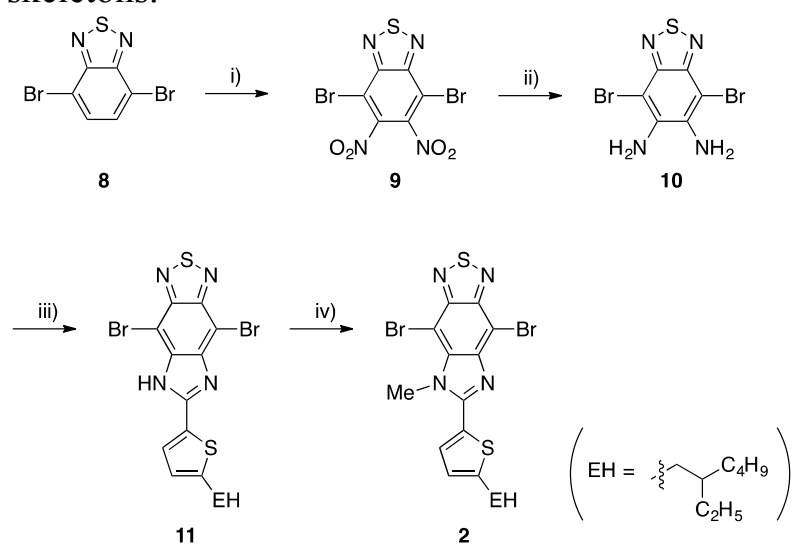

Scheme 2. Synthesis of imidazole-fused BT unit. Reagents and conditions: i) Fuming $\mathrm{HNO}_{3}$, conc. $\mathrm{H}_{2} \mathrm{SO}_{4}$, $50{ }^{\circ} \mathrm{C}, 23 \mathrm{~h}, 34 \%$; ii) $\mathrm{Fe}$ (12.0 equiv), $\mathrm{AcOH}, 50{ }^{\circ} \mathrm{C}, 8.5$ h, 77\%; iii) 5-(2-ethylhexyl)thiophene-2-carbaldehyde (1.1 equiv), TFA ( $20 \mathrm{~mol} \%$ ), DMSO, $100^{\circ} \mathrm{C}, 16.5 \mathrm{~h}$, then DDQ (2.6 equiv), $40^{\circ} \mathrm{C}, 0.5 \mathrm{~h}, 87 \%$; iv) MeI (2.0 equiv), $\mathrm{K}_{2} \mathrm{CO}_{3}$ (2.0 equiv), DMF, $100{ }^{\circ} \mathrm{C}, 16.5 \mathrm{~h}, 50 \%$. (a)

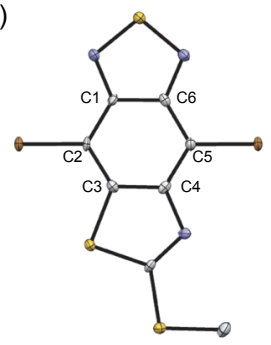

(b)

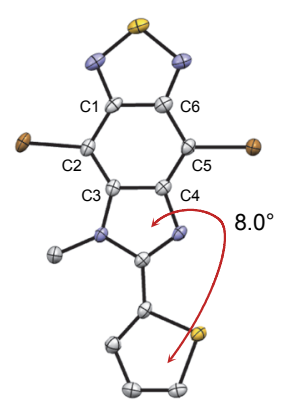

Fig. 3. Crystal structure of $\mathbf{1 a}$ and $\mathbf{2}$. All hydrogen atoms and 2-ethylhexyl group are omitted for clarity. Only selected atoms are labeled. (a) ORTEP drawing (thermal ellipsoids at $50 \%$ probability) of $\mathbf{1 a}$. Selected bond lengths $(\AA)$ : $\mathrm{C}(1)-\mathrm{C}(2), 1.411(7) ; \mathrm{C}(2)-\mathrm{C}(3), 1.370(8)$; $\mathrm{C}(3)-\mathrm{C}(4), 1.440(7) ; \mathrm{C}(4)-\mathrm{C}(5), 1.378(7) ; \mathrm{C}(5)-\mathrm{C}(6)$, 1.416(8); C(1)-C(6), 1.439(7). (b) ORTEP drawing of 2. Selected bond lengths $(\AA)$ : $C(1)-C(2), 1.423(5) ; C(2)$ $\mathrm{C}(3), \quad 1.371(5) ; \quad \mathrm{C}(3)-\mathrm{C}(4), \quad 1.449(5) ; \quad \mathrm{C}(4)-\mathrm{C}(5)$, 1.369(4); $\mathrm{C}(5)-\mathrm{C}(6), 1.415(6) ; \mathrm{C}(1)-\mathrm{C}(6), 1.443(6)$.

\subsection{Electrochemical properties}

To evaluate the effect of thiazole and imidazole fusion on the electrochemical properties of the BT skeleton, cyclic voltammograms of $\mathbf{1 a}-\mathbf{1 c}$ and $\mathbf{2}$ were recorded, and the results were compared with those of reference compound 8 (Fig. 4, Table 1). Thiazole-fused BT 1a with a methylthio group 
shows a reversible reduction wave at $E_{1 / 2}=-1.56 \mathrm{~V}$ (vs. $\mathrm{Fc} / \mathrm{Fc}^{+}$), which is shifted by ca. $0.12 \mathrm{~V}$ to less negative potential compared to that of non-fused derivative $8\left(E_{1 / 2}=-1.68 \mathrm{~V}\right)$. This result indicates the enhanced electron-accepting ability by thiazolefusion. 1b and 1c with methylsulfoxide and methylsulfonyl groups shift the reduction potential to less negative at $E_{\mathrm{pc}}=-1.41 \mathrm{~V}$ and $E_{\mathrm{pc}}=-1.26 \mathrm{~V}$, respectively, suggesting that the electron-accepting ability can be systematically enhanced by increasing the oxidation state of sulfur atom in methylthio group at the fused thiazole ring. In the oxidation

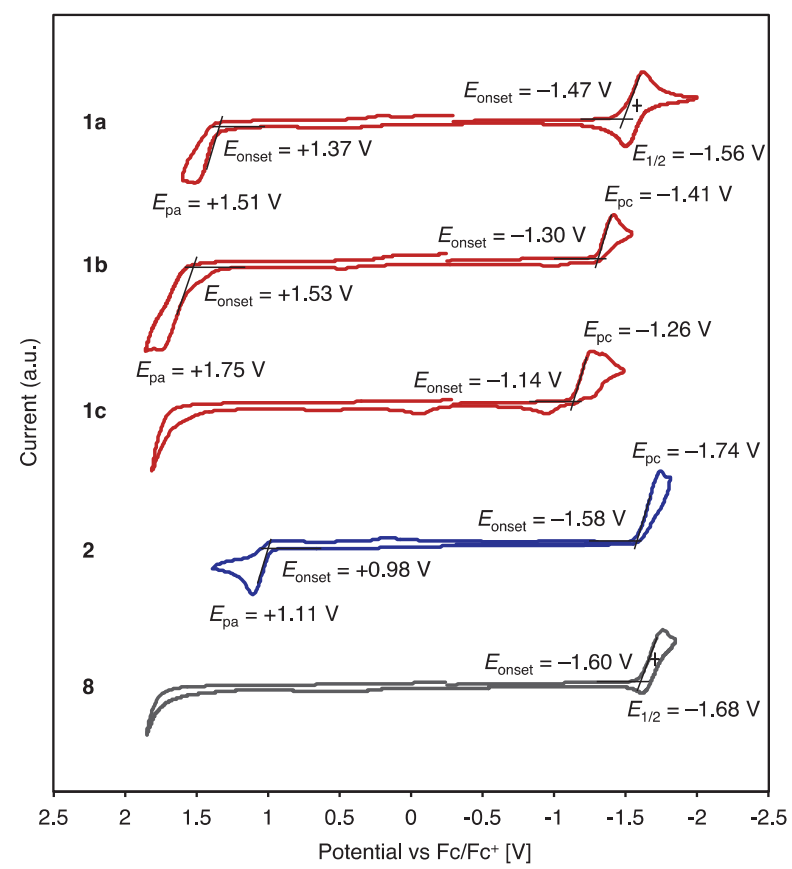

Fig. 4. Cyclic voltammograms of $\mathbf{1 a - 1 c}, \mathbf{2}$, and reference compound 8; recorded in $\mathrm{CH}_{2} \mathrm{Cl}_{2}(1 \mathrm{mM})$ at a scan rate of $100 \mathrm{mV} \mathrm{s}^{-1}$ using $n-\mathrm{Bu}_{4} \mathrm{NPF}_{6}(0.1 \mathrm{M})$ as the supporting electrolyte.

Table 1. Electrochemical properties of $\mathbf{1 a}-\mathbf{1 c}, \mathbf{2}$, and $\mathbf{8}$.

\begin{tabular}{|c|c|c|c|c|}
\hline & $E_{\text {ox }}[\mathrm{V}]^{\mathrm{a}}$ & $E_{\text {red }}[\mathrm{V}]^{\mathrm{a}}$ & $E_{\text {номо }}[\mathrm{eV}]^{\mathrm{b}}$ & $E_{\text {LUMO }}[\mathrm{eV}]^{\mathrm{b}}$ \\
\hline $1 a$ & $(+1.51)$ & -1.56 & -6.47 & -3.63 \\
\hline $1 b$ & $(+1.75)$ & $(-1.41)$ & -6.63 & -3.80 \\
\hline $1 c$ & - & $(-1.26)$ & $<-6.9$ & -3.96 \\
\hline 2 & $(+1.11)$ & $(-1.74)$ & -6.08 & -3.52 \\
\hline 8 & - & -1.68 & $<-6.9$ & -3.50 \\
\hline
\end{tabular}

process, 1a and $\mathbf{1 b}$ show oxidation waves at $E_{\mathrm{pa}}=$ $+1.51 \mathrm{~V}$ and $E_{\mathrm{pa}}=+1.75 \mathrm{~V}$, respectively, whereas no oxidation waves are observed for $\mathbf{1 c}$ and $\mathbf{8}$ in the potential window of $\mathrm{CH}_{2} \mathrm{Cl}_{2}(\sim+1.8 \quad \mathrm{~V})$. This suggests that electron-donating ability is slightly enhanced by thiazole-fusion, and can be controlled by the substitutents at the fused thiazole ring. As for imidazole-fused BT 2, an irreversible oxidation wave is observed at less positive potential of $E_{\mathrm{pa}}=$ $+1.11 \mathrm{~V}$ even compared with $\mathbf{1 a}(+1.51 \mathrm{~V})$, indicating that the electron-donating ability can be further enhanced on account of imidazole-fusion. The irreversible reduction wave at $E_{\mathrm{pc}}=-1.74 \mathrm{~V}$ indicates a subtle change in the electron-accepting ability. The HOMO and LUMO levels were estimated from these potentials (Table 1), which suggests the decrease of LUMO energy level by thiazole-fusion as well as the increase of HOMO energy level by imidazole-fusion.

\subsection{Theoretical calculations}

To gain insights into the effects of the azolefusion on the electronic structure, DFT calculations were conducted on model compounds $\mathbf{1 a}^{\prime}-\mathbf{1} \mathbf{c}^{\prime}, \mathbf{2}^{\prime}$, and $\mathbf{8}^{\prime}$, in which the bromine atoms were replaced by hydrogen atoms and the 2-ethylhexyl group was replaced by a methyl group (Fig. 5). The frontier orbitals of BT $\mathbf{8}^{\prime}$ indicate the considerable contribution of butadiene character, which is maintained in azole-fused BTs. The LUMO energy level is lowered by thiazole-fusion as well as

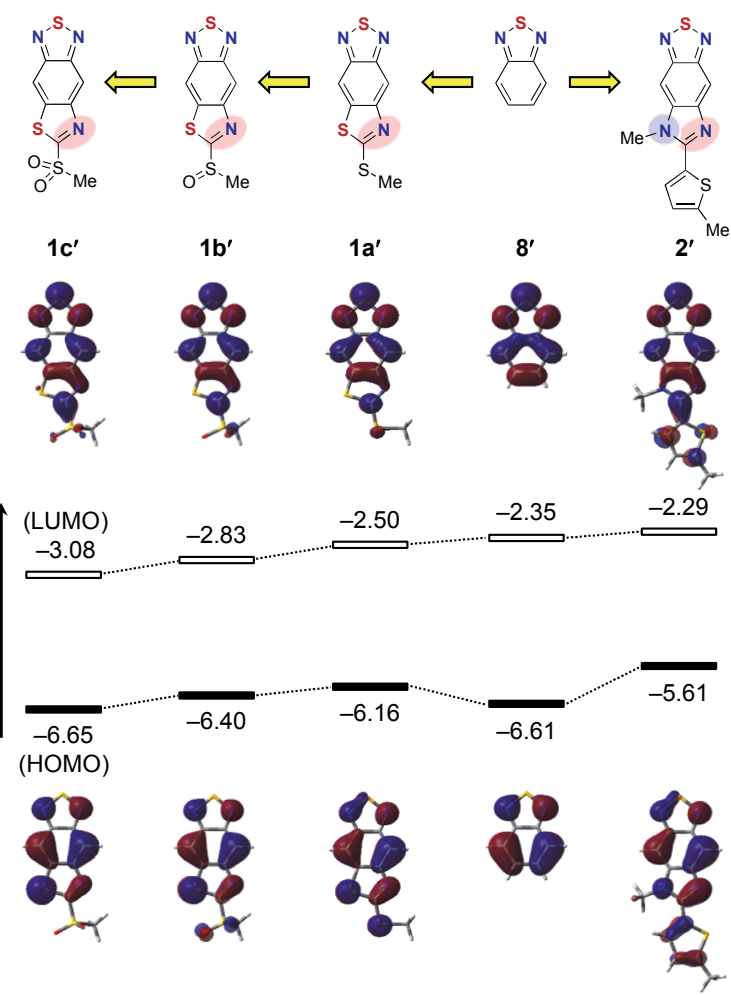

Fig. 5. Calculated energy diagram and depictions of the frontier orbitals of $\mathbf{1 a}^{\prime}-\mathbf{1 c}^{\prime}, \mathbf{2}^{\prime}$, and $\mathbf{8}^{\prime}$ (B3LYP/6-31G(d)) [13]. 
increasing the oxidation state of the attached sulfur atom of methylthio group, whereas the HOMO energy level is elevated by imidazole-fusion. These trends are qualitatively in good agreement with the experimental energy levels estimated from cyclic voltammetry.

\section{Conclusion}

In summary, two types of azole-fused benzothiadiazoles were designed and synthesized as new electron-accepting units. We exhibited that thiazole-fusion induces the lowering of the LUMO energy level, whereas imidazole-fusion increases the HOMO energy level while maintaining the LUMO energy level. Moreover, in thiazole-fused BT units, the electronic structure could be further modulated by varying the oxidation state of the sulfur atom in methylthio group at the fused thiazole ring. A variety of $\mathrm{D}-\mathrm{A}$ molecules and polymers would be developed using these electron-accepting units by combining with various electron-donating and $\pi$-conjugated units [25-32], which is currently in progress in our laboratory.

\section{Acknowledgements}

This research was partially supported by the Center of Innovation Program (COI) and Advanced Low Carbon Technology R\&D Program (ALCA) from Japan Science and Technology Agency, JST, "Low Carbon Technology Research and Development Program" from Ministry of the Environment, and JSPS KAKENHI Grant Number JP26288093. T.N. thanks JSPS fellowship for a Research Fellowship for Young Scientists.

\section{References}

1. J. Peet, A. J. Heeger, and G. C. Bazan, Acc. Chem. Res., 42 (2009) 1700.

2. J. Chen and Y. Cao, Acc. Chem. Res., 42 (2009) 1709.

3. O. Inganäs, F. Zhang, and M. R. Andersson, Acc. Chem. Res., 42 (2009) 1731.

4. G. Li, R. Zhu, and Y. Yang, Nat. Photonics., 6 (2012) 153.

5. J. Du, M. C. Biewer, and M. C. Stefan, J. Mater. Chem. A, 4 (2016) 15771.

6. T. C. Parker, D. G. D. Patel, K. Moudgil, S. Barlow, C. Risko, J.-L. Brédas, J. R. Reynolds, and S. R. Marder, Mater. Horiz., 2 (2015) 22.

7. Y. Wang and T. Michinobu, J. Mater. Chem. C, 4 (2016) 6200.

8. M. A. Naik and S. Patil, J. Polym. Sci., Part A:
Polym. Chem., 51 (2013) 4241.

9. Z. Yi, S. Wang, and Y. Liu, Adv. Mater., 27 (2015) 3589.

10. W. Li, K. H. Hendriks, M. M. Wienk, and R. A. J. Janseen, Acc. Chem. Res., 49 (2016) 78.

11. M. Satou, K. Uchinaga, A. Wakamiya, and Y. Murata, Chem. Lett., 43 (2014) 1386.

12. M. Satou, T. Nakamura, Y. Aramaki, S. Okazaki, M. Murata, A. Wakamiya, and Y. Murata, Chem. Lett., 45 (2016) 892.

13. Gaussian 09 (Revision A.02), M. J. Frisch, G. W. Trucks, H. B. Schlegel, G. E. Scuseria, M. A. Robb, J. R. Cheeseman, G. Scalmani, V. Barone, B. Mennucci, G. A. Petersson, H. Nakatsuji, M. Caricato, X. Li, H. P. Hratchian, A. F. Izmaylov, J. Bloino, G. Zheng, J. L. Sonnenberg, M. Hada, M. Ehara, K. Toyota, R. Fukuda, J. Hasegawa, M. Ishida, T. Nakajima, Y. Honda, O. Kitao, H. Nakai, T. Vreven, J. A. Montgomery, Jr., J. E. Peralta, F. Ogliaro, M. Bearpark, J. J. Heyd, E. Brothers, K. N. Kudin, V. N. Staroverov, R. Kobayashi, J. Normand, K. Raghavachari, A. Rendell, J. C. Burant, S. S. Iyengar, J. Tomasi, M. Cossi, N. Rega, J. M. Millam, M. Klene, J. E. Knox, J. B. Cross, V. Bakken, C. Adamo, J. Jaramillo, R. Gomperts, R. E. Stratmann, O. Yazyev, A. J. Austin, R. Cammi, C. Pomelli, J. W. Ochterski, R. L. Martin, K. Morokuma, V. G. Zakrzewski, G. A. Voth, P. Salvador, J. J. Dannenberg, S. Dapprich, A. D. Daniels, Ö. Farkas, J. B. Foresman, J. V. Ortiz, J. Cioslowski, and D. J. Fox, Gaussian, Inc., Wallingford CT, 2009.

14. G. M. Sheldrick, SHELX-97, Program for the Refinement of Crystal Structures; University of Göttingen: Göttingen, Germany, 1997.

15. L. Zhu and M. Zhang, J. Org. Chem., 69 (2004) 7371.

16. J. I. Park, B. L. Lee, and W. Chung, U. S. patent $13,569,552$.

17. B. Kohl, L. C. Over, T. Lohr, M. Vasylyeva, F. Rominger, and M. Mastalerz, Org. Lett., 16 (2014) 5596.

18. D. Zhao, Z. Zhu, M.-Y. Kuo, C.-C. Chueh, and A. K.-Y. Jen, Angew. Chem. Int. Ed., 55 (2016) 8999.

19. G. Zhang, Y. Fu, Q. Zhang, and Z. Xie, Polymer, 51 (2010) 2313.

20. G.-Y. Chen, S.-C. Lan, P.-Y. Lin, C.-W. Chu, and K.-H. Wei, J. Polym. Sci., Part A: Polym. Chem., 48 (2010) 4456.

21. M. Mahmut, T. Awut, I. Nurulla, and M. Mijit, $J$. Appl. Polym. Sci., 19 (2014) 40861. 
22. F. C. Teixeira, C. M. Rangel, and A. P. S. Teixeira, New J. Chem., 37 (2013) 3084.

23. M. Tomura and Y. Yamashita, Z. Kristallogr. NCS, 218 (2003) 555.

24. C. M. Cardona, W. Li, A. E. Kaifer, D. Stockdale, and G. C. Bazan, Adv. Mater., 23 (2011) 2367.

25. A. Wakamiya, H. Nishimura, T. Fukushima, F. Suzuki, A. Saeki, S. Seki, I. Osaka, T. Sasamori, M. Murata, Y. Murata, and H. Kaji, Angew. Chem. Int. Ed., 53 (2014) 5800.

26. H. Nishimura, N. Ishida, A. Shimazaki, A. Wakamiya, A. Saeki, L. T. Scott, and Y. Murata, J. Am. Chem. Soc., 137 (2015) 15656.

27. A. Wakamiya and S. Yamaguchi, Bull. Chem. Soc. Jpn., 88 (2015) 1357.
28. H. Nishimura, T. Fukushima, A. Wakamiya, Y. Murata, and H. Kaji, Bull. Chem. Soc. Jpn., 89 (2016) 726.

29. A. Wakamiya, H. Nishimura, and Y. Murata, $J$. Synth. Org. Chem. Jpn., 74 (2016) 1128.

30. H. Shimogawa, M. Endo, T. Taniguchi, Y. Nakaike, M. Kawaraya, H. Segawa, Y. Murata, and A. Wakamiya, Bull. Chem. Soc. Jpn., 90 (2017) 441.

31. H. Shimogawa, O. Yoshikawa, Y. Aramaki, M. Murata, A. Wakamiya, and Y. Murata, Chem. Eur. J., 23 (2017) 3784.

32. H. Shimogawa, M. Endo, Y. Nakaike, Y. Murata, and A. Wakamiya, Chem. Lett., DOI: 10.1246/cl.170087. 